УДК 616.6-06

DOI https://doi.org/10.11603/2312-0967.2021.4.12634

\title{
ФАРМАЦЕВТИЧНА ОПІКА ПРИ ВІДПУСКУ СТАНДАРТИЗОВАНИХ РОСЛИННИХ ЛІКАРСЬКИХ ЗАСОБІВ ПАЦІЕНТАМ ІЗ КАШЛЕМ
}

\author{
К. О. Зупанець, Т. С. Сахарова, Н. П. Безугла, І. А. Отрішко, С. К. Шебеко, \\ К. Л. Ратушна
}

Національний фрармацевтичний університет МОЗ України, Харків

clinpharm@nuph.edu.ua

ІНФОРМАЦІЯ

Надійшла до редакції / Received: 16.11.2021

Після доопрацювання / Revised: 06.12 .2021

Прийнято до друку / Accepted: 08.12 .2021

\section{Ключові слова:}

кашель;

фрармацевтична опіка; відповідальне самолікування; симптоматична терапія; технологія фрітонірингу; доказова медицина.

\begin{abstract}
АНОТАЦІЯ
Мета роботи. Оптимізація та удосконалення орармацевтичної опіки для забезпечення раціональної фрітотерапії пацієнтів при симптоматичному лікуванні кашлю із застосуванням рослинних препаратів, отриманих за оригінальною технологією фрітонірингу.

Матеріали і методи. Методологічну основу дослідження складають принципи об'єктивності і системності. У роботі використано комплекс загальнонаукових та спеціальних методів: теоретичний, метод узагальнення, систематизації даних, порівняння, методи вивчення літературних джерел і аналізу та ін.

Результати й обговорення. У роботі висвітлено основні принципи фрармацевтичної опіки пацієнтів із кашлем. Актуалізовано роль фрітотерапії в симптоматичному лікуванні кашлю та обґрунтовано раціональний вибір оптимального препарату 3 позицій доказової медицини. Представлено алгоритм фрармацевтичної опіки пацієнтів при симптоматичному лікуванні кашлю як одного 3 характерних симптомів запальних захворювань дихальних шляхів та алгоритм фрармацевтичної опіки при виборі та відпуску стандартизованих фрітопрепаратів у лікарській формі сиропу для симптоматичного лікування кашлю в дітей.

Висновки. Під час проведення фрармацевтичної опіки пацієнтів із кашлем першорядна рекомендація фрармацевтом стандартизованих рослинних лікарських засобів ґрунтується на вагомих даних доказової медицини щодо їх ефрективності і безпеки, а також прийнятності для застосування різними категоріями споживачів, включно дітей.
\end{abstract}

Вступ. Широке застосування інноваційних технологій у фрармації та створення рослинних лікарських засобів (РЛ3), ефективність і безпека яких науково обґрунтована, стало потужним поштовхом для нового етапу в розвитку сучасної фрітотерапії. Водночас наповнення фрармацевтичного ринку новими фрітопрепаратами неминуче породжує проблему вибору «правильного препарату», застосування якого забезпечуватиме прогнозований лікувальний результат.
Таким орієнтиром є низка критеріїв, за якими оцінюється відповідність препарату сучасним вимогам [1].

1. Якість вихідної сировини, з якої отримується фрітопрепарат. Рослинне походження сировини для виготовлення лікарського препарату - ще не доказ його достатньої безпеки для пацієнта. Якість рослинної сировини визначається (в основному, але не тільки!) умовами та ареалом зростання (вирощування). Окрім цього, рослинна сировина, вирощена в еколо-

ISSN 2312-0967. Pharmaceutical review. 2021. № 4 
гічно несприятливій місцевості, може бути забруднена такими токсичними для людини полютантами, як пестициди, солі важких металів, радіонукліди. Важливим є й кліматичні умови (наприклад, від кількості сонячних днів залежить вміст ефрірних олій у лікарській сировині), особливості ґрунту тощо.

2. Дотримання стандартизації сировини на всіх етапах створення фрітопрепарату - від вирощування до отримання кінцевого продукту, контроль якості продукції на всіх етапах її виробництва та забезпечення якості проведення доклінічних і клінічних досліджень.

3. Свідчення ефективності та безпеки фрітопрепарату на засадах доказової медицини. Погляди світової медичної громадськості сьогодні звернені до рослинних препаратів із підтвердженою і доведеною дією. Дотримання принципів наукової доказовості щодо ефективності і безпеки препаратів: проведення масштабних клінічних та доклінічних досліджень належного дизайну, що дають змогу отримати статистично достовірні порівняльні дані. Відповідність усім зазначеним принципам дасть змогу отримувати фрітопрепарати, які не тільки не поступаються синтетичним представникам відповідної групи, а навіть перевершують їх за співвідношенням клінічного ефекту і ризику розвитку побічних явищ. Свідченням прийняття лікарського засобу та високого ступеня довіри до нього є фракт включення його до клінічних настанов та протоколів, рекомендацій.

4. Важливою умовою для РЛЗ $є$ термін його перебування на фрармацевтичному ринку. 330 квітня 2011 р. у країнах ЄС почала діяти Директива з традиційних лікарських засобів рослинного походження (Директива 2004/24 / ЄС). Відповідно до цього нормативного документа виробництво рослинних ЛЗ має здійснюватися за правилами Належної виробничої практики (GMP) для забезпечення якості готової продукції, а також бути безпечною при застосуванні. Компанія, що висуває препарат на фрармацевтичний ринок, має продемонструвати, що фрітотерапевтичний засіб використовувався у ЄС щонайменше 30 років або 15 років в $Є С$ і 30 років за межами $Є C$.

5. Так званим «кредитом довіри» до препарату треба вважати його наявність на фрармацевтичному ринку багатьох країн світу, у тому числі і в країні походження пропрієтарного РлЗ.

6. Важливою умовою $€$ «статус» рослинного лікарського засобу. Знаходження на фрармацевтичному ринку у якості лікарського препарату, а не біологічно активної добавки (БАД) також свідчить про його якість, всебічне дослідження (в тому числі доклінічного, клінічного) і ступінь доказовості ефективності та безпеки.

7. Необхідно звернути увагу на ставлення виробника (його «турботу») до різних верств населення, а саме до найвразливішої групи населення - дітей. Наявність на ринку різноманітних лікарських фрорм пре- парату, що визначає можливість його адресності різним категоріям пацієнтів (окремо - педіатрична направленість), $€$ перевагою саме таких лікарських препаратів від інших.

8. Дотримання фрармацевтичних, технологічних, фрармакологічних, біофрармацевтичних принципів безпеки РЛ3, які визначаються не лише якісним та кількісним складом БАР рослинної сировини, але й складом і вмістом допоміжних речовин (особливо в педіатричній практиці).

Найкращою ілюстрацією такого підходу до створення фрітопрепаратів $€$ концепція фрітонірингу, яка запропонована німецькою компанією «Біонорика СЕ». Унікальна фрілософрія фрітонірингу об'єднує дослідження механізмів дії компонентів рослин із використанням інноваційних технологій і сучасних наукових методів (англ. phyto - рослина, engineering розробка, технологія).

Мета роботи - оптимізація та удосконалення фрармацевтичної опіки для забезпечення раціональної фрітотерапії пацієнтів при симптоматичному лікуванні кашлю із застосуванням рослинних препаратів, отриманих за оригінальною технологією фрітонірингу.

Матеріали і методи. Методологічну основу дослідження складають принципи об'єктивності і системності. У роботі використано комплекс загальнонаукових та спеціальних методів: теоретичний, метод узагальнення, систематизації даних, порівняння, методи вивчення літературних джерел і аналізу та ін.

Результати й обговорення. Одним із найбільш досліджених та широко застосовуваних у медичній практиці стандартизованих фрітопрепаратів компанії «Біонорика СЕ» (Німеччина) є Бронхипрет ${ }^{\circledR}$. Препарат призначений для лікування гострого бронхіту та запальних захворювань дихальних шляхів, що супроводжуються кашлем 3 утворенням в'язкого мокротиння. Основними та добре вивченими фармакологічними ефектами препарату Бронхипрет ${ }^{\circledR} \epsilon$ секретолітичний/муколітичний, протизапальний, противірусний, протимікробний та бронхоспазмолітичний. Перелічені фрармакологічні ефекти зумовлені комплексом біологічно активних речовин (БАР) таких рослин, як корінь первоцвіту весняного, трава чебрецю звичайного, листя плюща звичайного. Усі лікарські рослини, які складають «активне ядро» препарату, мають довготривалу історію застосування у народній медицині, а їх різнобічний лікувальний вплив на організм людини при різних захворюваннях та патологічних станах підтверджений багатовіковим емпіричним досвідом. На сьогодні усі зазначені лікарські рослини $€$ офріцінальними та внесені до Фармакопей багатьох країн, у тому числі України.

Випускається препарат у трьох лікарських фрормах (розчин, сироп, таблетки), що визначає адресність його призначення різним категоріям хворих [2].

Препарат має потужну доказову базу, яка ґрунтується на результатах великої кількості доклінічних і

ISSN 2312-0967. Фармацевтичний часопис. 2021. № 4 
клінічних досліджень, добре вивчений на клітинному та молекулярному рівнях [1]. Завдяки доведеним високій ефрективності і гарній переносимості (як у дорослих, так і у дітей) він є єдиним РЛЗ, який двічі було включено до Настанов з лікування гострого кашлю у Німеччині (AWMF S3 NO. 020/003 - «Diagnosis and therapy of adult patients with acute and chronic coughs» 02.2010; Leitlinie der Deutschen Gesellschaft für Pneumologie und Beatmungsmedizin zur Diagnostik und Th erapie von erwachsenen Patienten mit akutem und chronischem Husten Guidelines of the German Respiratory Society for Diagnosis and Treatment of Adults Suff ering from Acute or Chronic Cough, 2018).

Окрім того, фрітонірингові препарати входять до Європейських рекомендацій щодо лікування гострих і поліпозних риносинуситів (European Position Paper on Rhinosinusitis and Nasal Polyps - EPOS 2020), в Україні їх включено до «Уніфікованого клінічного протоколу первинної, вторинної (спеціалізованої) та третинної (високоспеціалізованої) медичної допомоги: гострий риносинусит» (наказ МОЗ України від 11.02.2016 p № 85 «Про затвердження та впровадження медико-технологічних документів зі стандартизації медичної допомоги при гострих запальних захворюваннях верхніх дихальних шляхів та вуха») $[3,4]$.

Аналіз фрармацевтичного ринку рослинних лікарських препаратів для симптоматичного лікування кашлю показав, що переважну частку асортименту складають л3, які за складом лікарських рослин $є$ тотожними до Бронхипрету ${ }^{\circledR}$, до того ж, деякі «аналоги» $€$ більш привабливі для споживачів за ціною. У більшості випадків пацієнти $з$ кашлем починають лікуватися самостійно і досить часто першим, до кого вони звертаються, є провізор. Отже, питання «правильного вибору правильного препарату правильному пацієнту» лежить у сорері повсякденної професійної діяльності фрармацевта, який повинен знати про переваги і недоліки, «плюси» і «мінуси» рослинних лікарських засобів подібного складу.

Треба зауважити, що у чинних рекомендаціях Німецького респіраторного товариства з діагностики та лікування гострого, підгострого і хронічного кашлю у дорослих (2019р.) чітко виокремлено: «...Вміст активної речовини, а отже, ефективність, залежить від багатьох фракторів: походження використовуваних рослин, методу екстракції, стандартизації і виробничого процесу. Тому різні екстракти лікарських рослин не є взаємозамінними. Результати досліджень із застосуванням рослинних лікарських засобів $€$ справедливими лише для продукту, що тестується. Вони не можуть екстраполюватися на інші екстракти з даного «ботанічного виду».

\section{Елементи фрармацевтичної опіки пацієнтів при симптоматичному лікуванні кашлю}

На першому етапі фармацевтичної опіки задача срармацевта полягає у з'ясуванні та уточненні ймо- вірної причини виникнення нездужання. Безперечно, що й лікування кашлю треба починати з усунення його причини. Найчастіше причиною звернення пацієнта до аптеки за лікарським препаратом для симптоматичного лікування кашлю $є$ гостра респіраторна вірусна інфекція (ГРВІ). Зважаючи на те, що кашель - це захисна реакція організму, основна мета лікування кашлю при ГРВІ полягає не у пригніченні кашльового рефлексу (протикашльові препарати), а у сприянні переходу сухого кашлю на кашель із мокротинням (відхаркувальні і муколітичні препарати), що, у свою чергу, сприятиме «очищенню» бронхів не лише від мокротиння, а й від збудника (елімінація патогену). Лише у тих випадках, коли кашель втрачає свою фрізіологічну доцільність і стає болісним, нав'язливим, малопродуктивним, спричиняє фрізичний і психологічний дискомфорт та суттєво знижує якість життя пацієнта та членів його родини (порушення сну внаслідок нічного кашлю), необхідне застосування Л3, що чинять протикашльову дію.

У перші дні ГРВІ, як правило, з'являється сухий кашель чи навіть лише ознаки подразнення рефлексогенних зон верхніх дихальних шляхів через запальний набряк слизової (першіння у горлі, покашлювання), але вже через 2-3 дні він стає вологим, триваючи до 10-14 діб на тлі інших залишкових явищ захворювання. Такий перебіг захворювання є природним (тривалість одного випадку кашлю, викликаного інфрекцією верхніх дихальних шляхів (ІВДШ), різна, втім рідко перевищує 2 тижні). Загалом ГРВІ являє собою гостре самокупірувальне, самовиліковне захворювання, яке зазвичай завершується повним одужанням і відновленням фрункцій слизової оболонки дихальних шляхів. Однак призначення симптоматичного лікування полегшує стан хворого і підтримує адаптаційно-пристосовувальні властивості організму в процесі одужання, до того ж, на відміну від інших симптомів ГРВІ, як зазначалось вище, лікування кашлю треба починати якомога раніше. Саме тому рослинні препарати з біологічно активними речовинами, що мають протизапальну дію, доцільно використовувати і при сухому кашлі, оскільки усувається набряк і запалення рефлексогенних зон у дихальних шляхах $[5,6]$.

За статистикою 50 \% хворих із гострим кашлем внаслідок ІВДШ лікуються самостійно, орієнтуючись на власний досвід, тому одним із важливих завдань фрармацевта, який першим взаємодіє саме з такою категорією споживачів, полягає у виборі та рекомендації Рлз з оптимальним співвідношенням ефективність/безпека, яке визначено з позицій доказової медицини [7-9]. Алгоритм фрармацевтичної опіки пацієнта 3 кашлем при відпуску РЛЗ наведено на рисунку 1.

Загальні рекомендації для пацієнтів із кашлем:

- утримуватися від куріння, у тому числі від пасивного вдихання цигаркового диму;

ISSN 2312-0967. Pharmaceutical review. 2021. № 4 


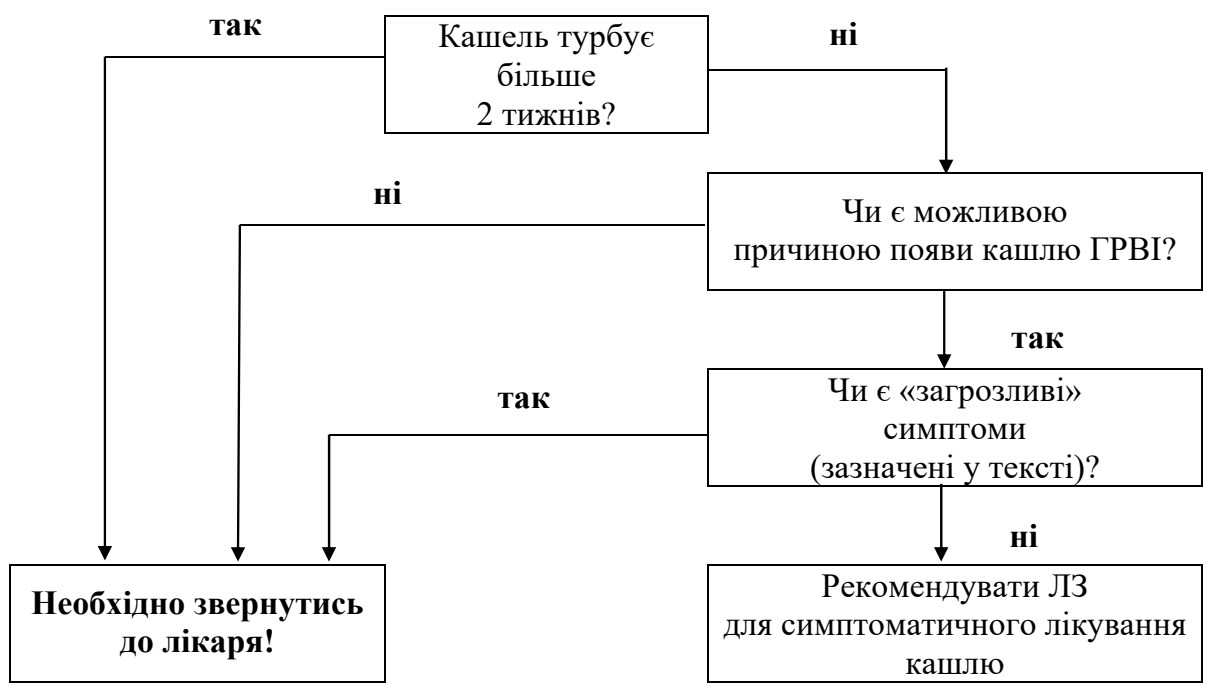

Рис. 1. Алгоритм фрармацевтичної опіки пацієнта з кашлем при відпуску стандартизованих рослинних лікарських засобів.

- частіше провітрювати приміщення, адже чисте прохолодне повітря пригнічує кашльовий рефрлекс;

- уникати переохолодження;

- постійно дотримуватися правил особистої гігієни;

- забезпечити збалансоване повноцінне харчування та надходження вітамінів і мікроелементів з їжею (або у складі полівітамінних препаратів);

- більше відпочивати та організовувати нетривалі прогулянки на свіжому повітрі.

Профресійно грамотний та зважений підхід до симптоматичного лікування кашлю з рекомендацією «правильного препарату» не обмежується лише його вибором. Не менш важливим для досягнення надійного лікувального ефекту є дотримання правил вірного дозування препарату, тривалості приймання та умов раціонального застосування. На сьогодні препарат представлений у трьох лікарських фрормах (розчин, сироп, таблетки), що визначає його адресність різним категоріям хворих. Різноманітність форм випуску препарату дає змогу коректно підібрати адекватну терапію з урахуванням індивідуальних потреб кожного пацієнта, що загалом сприятиме підвищенню комплаєнсу, а також враховувати фрармакоекономічні переваги. Кожна із лікарських фрорм має свої особливості призначення, на чому необхідно обов'язково акцентувати увагу відвідувачів аптек. Так, до складу Бронхипрет ${ }^{\circledR}$ розчину та Бронхипрет ${ }^{\circledR}$ сиропу входять екстракт трави чабрецю рідкого та екстракт із листя плюща рідкого, а Бронхипрет ${ }^{\circledR}$ ТП таблетки містять екстракт трави чебрецю сухого і екстракт кореня первоцвіту сухого. Використання різних лікарських рослин у різних лікарських фрормах не змінює профріль ефективності та доказовості препаратів. Дорослим та дітям віком від 12 років Бронхипрет ${ }^{\circledR}$ ТП таблетки, вкриті оболонкою, треба приймати по 1 таблетці 3 рази на добу. Бронхипрет ${ }^{\circledR}$ ТП таблетки треба приймати не розжовуючи, з достатньою кількістю рідини (переважно склянкою води) перед їдою. Дозу лікарського засобу Бронхипрет ${ }^{\circledR}$ розчин вимірюють за допомогою мірного ковпачка та застосовують відповідно до віку згідно з інструкцією до медичного застосування.

Фармацевт несе відповідальність за призначену фарматерапію і залишається консультантом хворого впродовж усього терміну приймання обраного ним препарату. Так, при прийманні будь-яких мукоактивних ЛЗ важливою умовою для досягнення лікувального едекту та відходження мокротиння є дотримання адекватного питного режиму. Посилення кашлю та певне збільшення об'єму мокротиння, що відходить, яке може спостерігатися на 2-3 добу приймання мукоактивних Л3, не є показанням для відміни препарату, а свідчить про його ефективність. Потрібно враховувати й можливу взаємодію фрітопрепаратів із препаратами інших груп, які приймає хворий. Згущення мокротиння та пригнічення його евакуації спостерігається при приймання антихолінергічних, адренергічних, антигістамінних препаратів, сечогінних, проносних тощо, що призводить до зниження ефективності відхаркувальних і муколітичних засобів. Це набуває особливого значення у випадках, що стосуються педіатричної практики, осіб з обтяжливим коморбідним тлом, у тому числі пацієнтів із цукровим діабетом, захворюваннями серцево-судинної системи (тих, хто приймають сечогінні ЛЗ, серцеві глікозиди та ін.) та схильністю до атопії. Недоцільне застосування фрітопрепаратів разом із синтетичними протикашльовими препаратами, адже це погіршує процес відкашлювання мокротиння.

Окремої уваги фрармацевта потребують декретовані категорії відвідувачів аптеки - вагітні та жінки, які годують груддю, особи з хронічними захворюваннями (гастритом або виразкою шлунка; цукровим діабетом; при лікуванні від алкоголізму (протипоказані

ISSN 2312-0967. Фармацевтичний часопис. 2021. № 4 
лікарські фрорми із вмістом етанолу; у разі спадкової непереносимості галактози, лактазною недостатністю або з порушенням всмоктування глюкози-галактози). Зазвичай при виборі РЛС обов'язковим є урахування алергологічного анамнезу: Бронхипрет ${ }^{\circledR}$ протипоказаний при підвищеній індивідуальній чутливості до будь-якого $з$ компонентів препарату, а також до інших лікарських рослин родини губоцвітих або аралієвих, до пилку берези, полину та селери.

Тривалість лікування препаратом Бронхипрет ${ }^{\circledR}$ залежить від перебігу захворювання, але зазвичай курс лікування становить 7 днів. За необхідності тривалішого лікування або якщо симптоми захворювання тривають чи прогресують більше тижня, треба звернутися до лікаря. Консультація лікаря потребує наявність таких проявів (які мають статус «загрозливих» симптомів) [10]:

- кашель, що триває більше 3-х тижнів (особливо у тих випадках, коли з перебігом часу кашель невпинно прогресує);

- кашель, що невпинно прогресує у дітей, може свідчити про аспірацію стороннього тіла;

- кашель, що супроводжується довготривалою (зберігається тижнями) лихоманкою - 37,5-38,0 ${ }^{\circ}$;

- кашель, що супроводжується гіпертермією (38,039,0 $0^{\circ}$ ) впродовж трьох і більше діб;

- кашель, що супроводжується задишкою або болем у грудній клітці при диханні;

- кашель, що супроводжується кровохарканням, пов'язаний з нічним потінням/втратою маси тіла;

- кашель із нападами задухи;

- раптовий напад сильного кашлю;

- сильний кашель впродовж години без перерви;

- зміна тембру голосу.

I лише за умови, якщо жоден із «загрозливих» симптомів у відвідувача аптеки не виявлений, можна розпочинати наступний етап фрармацевтичної опіки - вибір для даного пацієнта найприйнятнішого за рівнем доказовості РЛЗ для симптоматичного лікування кашлю.

\section{Критерії вибору та відпуску стандартизованих фітопрепаратів у лікарській формі сиропу для симптоматичного лікування кашлю у дітей}

Актуальність симптоматичного лікування кашлю у дітей зумовлена високою частотою захворюваності на ГРВІ; суттєвими відмінностями клінічного перебігу залежно від віку; наявності дитячих інфекційних захворювань, що маскуються під ГРВІ; коморбідних станів (бронхіальна астма, цукровий діабет, захворювання шлунково-кишкового тракту тощо); дефіцитом прийнятних лікарських фрорм; «відкритим питанням» безпеки допоміжних речовин у складі «дитячих» ліків. У більшості дітей кашель, як прояв ГРВІ, самостійно розрішується впродовж 14 діб, але у деяких випадках кашель може тривати до 4 тижнів або прогресувати, набуваючи більш тяжкого характеру (за частотою і вираженістю). Більшість батьків звертається до аптеки за безрецептурними лз для симптоматичного лікування ГРВІ, зокрема, кашлю, з перших днів появи симптомів. У рамках фрармацевтичної опіки фрармацевт має впевнитись, що причиною кашлю $€$ ГРВІ та виключити можливі «загрозливі» симптоми. Для цього необхідно з'ясувати: як довго триває кашель; чи є контакт у дитини з тютюновим димом; характеристика (сухий чи вологий, нічний тощо); наявність інших симптомів; особливості сімейного анамнезу (хронічні захворювання органів дихання, алергічні стани); які Л3 вже застосовувались.

В усьому світі склалася усталена тенденція до вибору батьками для симптоматичного лікування кашлю РЛЗ як найбільш безпечних (природних, із величезним досвідом застосування, відомих багатьом поколінням) [11]. У дитячій практиці переважаючим уподобанням батьків/дітей $є$ РЛЗ у фрормі сиропів. Необхідно зауважити, що співвідношення ефективність/ безпека дитячих лікарських фрорм (ЛФ), які є складними багатокомпонентними терапевтичними системами, зумовлюється не лише фрармакологічними властивостями БАР РЛЗ, а й особливостями технології, серед яких перше місце посідає склад допоміжних речовин. Саме допоміжні речовини, серед іншого, мають забезпечувати терапевтичний ефект, високу безпеку та стабільність РЛЗ, а також мати приємні органолептичні властивості, прийнятні для дитини.

При створенні ЛЗ у фрормі сиропів використовують певні групи допоміжних речовин (розчинники, загусники, коригенти смаку, запаху, кольору, рН середовища, консерванти, які є так званими Е-добавками), бажано використовувати переважно натуральні, безпечні речовини, які дозволені для застосування внутрішньо. Більшість Е-добавок (речовини, які використовуються при технологічній розробці ЛЗ), що входять до складу дитячих сиропів, мають доведену безпеку, яка підтверджена багаторічним досвідом застосування. Проте вживання деяких Е-добавок пов'язано з ризиком виникнення негативних явищ, особливо у певних категорій пацієнтів, насамперед, із супутньою патологією, що особливо актуально для дітей. Так, наприклад, деякі підсолоджувачі (сорбітол, ксиліт, штучні підсолоджувачі), консерванти (зокрема, парабени), розчинники (пропіленгліколь, гліцерин), синтетичні барвники становлять певний ризик для організму дитини [12]. Зважаючи на те, що щорічно діти, які часто хворіють, взагалі можуть отримувати до 2 л сиропу від кашлю, це підвищує ризик розвитку негативних реакцій, зумовлених деякими Е-добавками. Окрім того, необхідно врахувати можливості негативної взаємодії їх між собою чи з іншими Л3, які приймають одночасно у складі комплексної терапії.

Із усього переліку допоміжних речовин, які дозволені сучасними вимогами у складі дитячих лікарських фрорм, виокремлюються певні риси «ідеального» компоненту. Так, бажано, аби коригенти органолеп-

ISSN 2312-0967. Pharmaceutical review. 2021. № 4 
тичних показників (колір, запах і смак) не ототожнювали сироп із кондитерським виробом, аби не приваблювати дитину. Вміст спирту етилового в лікарських препаратах для дітей є безпечним, якщо він не перевищує такий у продуктах дитячого харчування (кефрір, яблучний та виноградний сік та ін.), оскільки у дітей (до 15 років) відсутній фермент альдегіддегідрогеназа, що відповідає за метаболізм спирту етилового. Як загусники (допоміжні речовини, які покращують в'язкість дисперсних систем, поліпшують і зберігають їх структуру, позитивно впливають на сприйняття смаку та створюють необхідні реологічні властивості) у фрармацевтичному виробництві різних країн світу використовують пектин, сорбіт (сорбітол), манітол, гліцерин, глюкозу, метилцелюлозу, камедь, полідекстрозу, найчастіше з яких - гліцерин та сорбітол. Доведеним фактом щодо небажаних наслідків перорального застосування гліцерину (у складі сиропу) $€$ його здатність чинити легку проносну дію, а у великих дозах - головний біль, спрагу, нудоту та гіперглікемію. Сорбітол та манітол можуть також спричинювати послаблювальний ефект, особливо при схильності до діареї, та викликають виражений метеоризм. Деякі із загусників мають солодкий смак і використовуються як підсолоджувачі. Використання підсолоджувачів із високим глікемічним індексом (сахароза) $є$ обмеженим у дітей з цукровим діабетом, ожирінням. Часто прихованою небезпекою підсолоджувачів $€$ їхня каріогенність (це найхарактерніше глюкозі та сахарозі). Щодо вмісту барвників у сиропах (дозволеними в Україні $€$ E100-E182), то вони мають бути або природного походження, або взагалі не міститись у складі дитячої лікарської фрорми. Застосовувані синтетичні барвники характеризуються високим профілем безпеки, їх перелік схвалюється відповідними регуляторними органами. Так, барвник E124 (Понсо червоний) входить до «чорного списку» в країнах ЄС вже близько 10 років, оскільки доведено, що його тривале застосування призводить до гіперчутливості, гіперкінетичної активності у дітей, затримки розвитку. Обов'язковим компонентом сиропів $€$ консерванти, які мають захищати від мікробної контамінації та збільшують термін зберігання. Завищена концентрація консервантів може викликати алергічні реакції. Проте $є$ консерванти, які навіть у дозволеному вмісті здатні виявляти сенсибілізуючу дію. Так, добавка E218 (метилпарагідроксибензоат) може бути потенційним тригером для розвитку реакцій гіперчутливості сповільненого типу.
Аналіз складу допоміжних речовин стандартизованого рослинного (фітонірингового) лікарського препарату Бронхипрет ${ }^{\circledR}$ компанії «Біонорика СЕ» у дитячій лікарській фрормі сиропу продемонстрував його оптимальне співвідношення діючих та допоміжних речовин [12]. Останнє зумовлює його високу ефективність та безпеку при лікуванні кашлю у дітей усіх вікових груп та обґрунтовано його популярність не лише на фрармацевтичному ринку України, але і країн Європи. Препарат не містить парабенів, заборонених синтетичних барвників, а загусник/підсолоджувач (мальтитол) має природне походження (отримують шляхом гідролізу кукурудзяного крохмалю). До того ж, мальтитол організм засвоює повільніше, ніж сахарозу, має у два рази меншу калорійність і менший вплив на рівень глюкози в крові, ніж звичайний цукор i, тому більш безпечний для дітей з цукровим діабетом. Даний підсолоджувач не сприяє розмноженню бактерій в порожнині рота, і тому не провокує розвиток карієсу (низька каріогенність). При недотриманні режиму дозування (надмірному вживанні), як і більшість інших цукрових спиртів, він може діяти як проносне, при цьому можуть мати місце дискомфорт у животі, метеоризм. Проте при застосуванні у рекомендованих дозах такі явища виникають дуже рідко і лише за наявності схильності до діареї.

Тому задля точного дозування Бронхипрет ${ }^{\circledR}$ сироп передбачений мірний ковпачок і відповідний режим застосування (табл.).

Бронхипрет ${ }^{\circledR}$ у формі сиропу можливо приймати разом із їжею і напоями або незалежно від приймання їжі. Нерозведений сироп Бронхипрет ${ }^{\circledR}$ рекомендовано запивати невеликою кількістю рідини (переважно водою), для дітей віком до 6 років разову дозу сиропу можна розвести у столовій ложці рідини. Якщо у пацієнта «чутливий» шлунок, Бронхипрет ${ }^{\circledR}$ у фрормі сиропу треба приймати після їди.

Таким чином, розуміння фрармацевтом біофармацевтичних особливостей ліків визначає зважений підхід до оцінки правильності вибору РлЗ у дитячих лікарських фрормах (сиропі) як при безпосередній взаємодії з представниками пацієнта (батьками) в аптеці, так і при фрармацевтичній опіці (консультуванні) лікаря-педіатра. Основою взаємодії між фрармацевтом і батьками є двобічна відповідальність. 3 боку провізора - за скеровування дій батьків залежно від ситуації (стан дитини, тривалість нездужання, необхідність консультації лікаря між іншим), з боку батьків - за надання об'єктивної інсрормації щодо конкретного не-

\section{Таблиця}

Дозування Бронхипрет ${ }^{\circledR}$ сироп

\begin{tabular}{|c|c|c|}
\hline Вік, років & Дозування у мл (3 рази на добу) & Добова доза, мл \\
\hline $2-5$ & 3,2 & 9,6 \\
\hline $6-11$ & 4,3 & 12,9 \\
\hline$\geq 12$ & 5,4 & 16,2 \\
\hline
\end{tabular}

ISSN 2312-0967. Фармацевтичний часопис. 2021. № 4 
здужання у дитини та його можливих причин, проведених лікувальних заходів. Найважливішим при взаємодії фрармацевта з батьками є з'ясування наявності «загрозливих симптомів», які вимагають негайної консультації лікаря: гарячка, тахіпное, що тривають; порушення ковтання; зміна тембру; біль у грудній клітці при вдиху або видиху; наявність блювання; надсадний кашель або зі «свистом»; зміна кольору обличчя при кашлі; виражена слабкість та швидка стомлюваність та інші симптоми, які не характерні для неускладненого перебігу ГРВІ.

Алгоритм фрармацевтичної опіки при відпуску РлЗ для симптоматичного лікування кашлю у дітей наведено на рисунку 2.

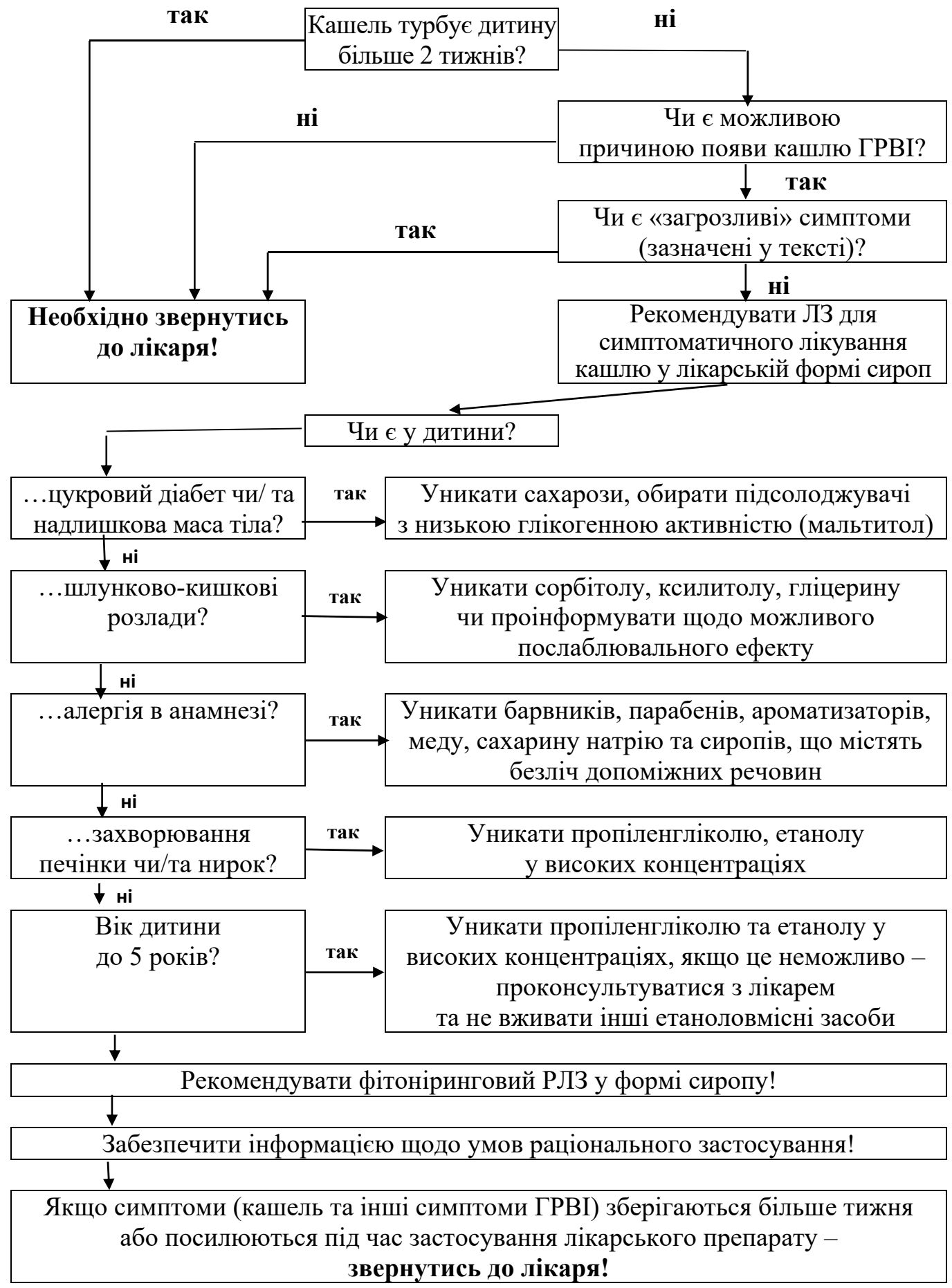

Рис. 2. Алгоритм фрармацевтичної опіки при виборі та відпуску стандартизованих фрітопрепаратів у лікарській формі сиропу для симптоматичного лікування кашлю у дітей.

ISSN 2312-0967. Pharmaceutical review. 2021. № 4 
При виборі Бронхипрету ${ }^{\circledR}$ у фрормі сиропу фрармацевт має переконатися, що батьки вірно зрозуміли надану їм інформацію, акцентувати увагу, що необхідно звернутися до лікаря:

- при перших ознаках будь-якої побічної реакції (обов'язково одразу припинити застосування препарату);

- якщо симптоми (кашель та інші симптоми ГРВІ) зберігаються більше тижня або посилюються під час застосування препарату Бронхипрет ${ }^{\circledR}$ сироп;

- якщо виникають наведені вище «загрозливі симптоми».

До першорядних завдань з лікування ГРВІ належать рекомендації з немедикаментозних заходів та дотримання належних санітарно-гігієнічних умов, про які фрармацевт має нагадати батькам: дитина повинна перебувати в комфортних умовах (температура повітря $20-22^{\circ} \mathrm{C}$ з достатньою його вологістю); в оточуючому дитину середовищі не повинно бути подразнювальних різких запахів, насамперед, тютюнового диму тощо; дієта повинна включати рідкі каші, картопляне пюре, треба виключити прянощі; вживати підвищену кількість теплої рідини (чай, морси, негазовані лужні мінеральні води тощо).

Надання цієї інсрормації батькам може знизити потребу в наступних консультаціях лікаря, підвищить якість життя дитини та родини в цілому, буде сприяти скороченню тривалості захворювання та запобіганню розвитку ускладнень.

Висновки. При проведенні фармацевтичної опіки пацієнтів із кашлем першорядна рекомендація фрармацевтом стандартизованих фрітонірингових препаратів ґрунтується на вагомих даних доказової медицини щодо їх едективності і безпеки, а також прийнятністю для застосування різними категоріями споживачів, включно дітей.

Конфрлікт інтересів: відсутній.

Conflicts of interest: authors have no conflict of interest to declare.

\title{
PHARMACEUTICAL CARE WHILE DISPENSING STANDARDIZED HERBAL MEDICINES FOR PATIENTS WITH COUGH
}

\author{
K. O. Zupanets, T. S. Sakharova, N. P. Bezugla, I. A. Otrishko, S. K. Shebeko, K. L. Ratushna \\ National University of Pharmacy of the Ministry of Health of Ukraine, Kharkiv, Ukraine \\ clinpharm@nuph.edu.ua
}

The aim of the work. Optimization and improvement of pharmaceutical care in providing rational herbal medicine of patients at symptomatic treatment of cough with the use of herbal medicines produced by the original phytoneering technology. Materials and Methods. The research methodology is based on the principles of objectivity and consistency. In the work a complex of general scientific and special methods: theoretical, method of generalization, systematization of data, comparison, methods of studying literary sources and analysis, etc. have been used.

Results and Discussion. The article highlights the basic principles of pharmaceutical care for patients with cough. The role of herbal medicine in the symptomatic treatment of cough is actualized and the rational choice of the optimal drug from the standpoint of evidence-based medicine is substantiated. The algorithm of pharmaceutical care of patients at symptomatic treatment of cough as one of the characteristic symptoms of inflammatory diseases of the respiratory tract and the algorithm of pharmaceutical care while choosing and dispensing the standardized herbal medicines in the dosage form of syrup for the symptomatic treatment of cough in children are presented.

Conclusions. During the pharmaceutical care of patients with cough, the pharmacist's primary recommendation of standardized herbal medicines is based on strong evidence-based data on their effectiveness and safety, as well as acceptability for use by different categories of consumers, including children.

Key words: cough; pharmaceutical care; responsible self-medication; symptomatic therapy; technology of phytoneering; evidence-based medicine.

\section{Список бібліографрічних посилань}

1. Фармацевтична опіка пацієнтів при симптоматичному лікуванні кашлю: метод. рек. / К. О. Зупанець та ін. - Харків : Золоті сторінки, 2021. 52 с.

2. Компендиум 2020 - лекарственные препараты / под ред. В. Н. Коваленко ; науч.-редакц. совет : В. Н. Коваленко, С. В. Сур, И. А. Зупанец. Киев : Морион, 2020. 2560 с.
3. EPOS 2020: European position paper on rhinosinusitis and nasal polyps 2020. W. J. Fokkens, V. J. Lund, C Hopkins et al. Rhinology. - 2020. - Vol. 58 (Suppl. 29). - P. 1-464.

4. Унісікований клінічний протокол первинної, вторинної (спеціалізованої) та третинної (високоспеціалізованої) медичної допомоги

ISSN 2312-0967. Фармацевтичний часопис. 2021. № 4 
гострий риносинусит [Електронний ресурс]. URL: https://medprosvita.com.ua/unifi kovaniyklinichniy-protokol-gostriy-rinosinus-6.

5. Вакуленко Л. И., Самохина И. И. Возможности фритотерапии в профилактике острого бронхита как осложнения ОРВИ. Medical Nature. 2012. № 4, декабрь. С. 34-38. http://nbuv.gov.ua/UJRN/ simmed_2015_5_44

6. Попп М. Гострий бронхіт: фрітотерапія 3 позиції доказової медицини. Здоров'я України : темат. номер «Педіатрія». 2019. № 4 (51). С. 23. http:// www.health-ua.com

7. Кардош П. Фітотерапія при гострому бронхіті: які докази ми маємо? Здоров'я України. 2019. № 18 (463). C. 43-44. http://www.health-ua.com

8. Antimicrobial-resistant pathogens associated with healthcare-associated infections: summary of data reported to the National Healthcare Safety Network

\section{References}

1. Zupanets KO, Sakharov TS, Otrishko IA. Pharmaceutical care of patients with symptomatic treatment of cough: guidelines. Фармацевтична опіка пацієнтів при симптоматичному лікуванні кашлю: метод. рек. Kharkiv: Zoloti storinky. Ukrainian.

2. Kovalenko VN, Sur SV, Zupanets IA. Compendium 2020 - drugs. Kyiv: Morion; 2020. Russian.

3. Fokkens WJ, Lund VJ, Hopkins C. EPOS 2020: European position paper on rhinosinusitis and nasal polyps 2020. Rhinology. 2020;58(29): 1-464.

4. Unified clinical protocol of primary, secondary (specialized) and tertiary (highly specialized) medical care: acute rhinosinusitis [Унісрікований клінічний протокол первинної, вторинної (спеціалізованої) та третинної (високоспеціалізованої) медичної допомоги: Гострий риносинусит]. [Electronic resource]. Available from: https://medprosvita.com.ua/unifi kovaniyklinichniy-protokol-gostriy-rinosinus-6. Ukrainian.

5. Vakulenko L.I., Samochina I.I. [Features of phytotherapy in the prevention of acute bronchitis as a complication of ARVI]. Vozmozhnosti fitoterapii $\mathrm{V}$ profilaktike ostrogo bronkhita kak oslozhneniya ORVI]. Medical Nature. 2012; 4. 34-38. http://nbuv.gov.ua/ UJRN/simmed_2015_5_44 Russian.

6. Popp M. [Acute bronchitis: Phytotherapy from the position of evidence-based medicine]. Zdorovia Ukrainy: at the Centers for Disease Control and Prevention, 2009-2010. Infect. Control. Hosp. Epidemiol. 2013. Vol. 34 (1). P. 1-14. https://doi/org/10.1086/668770. Epub 2012 Nov 27.

9. Kardos P. Phytotherapy in acute bronchitis: what is the evidence? Clinical Phytoscience. 2015;1: 2. DOI: 10.1186/s40816-015-0003-2.

10. Chernykh VP, Zupanets IA, Lischishina OM. Protocols of Pharmaceutist (Pharmacist) [Протоколи провізора (фрармацевта)]. Kharkiv: NUPh: Zoloti storinky. 2014. Ukrainian.

11. Chevallier A. Encyclopedia of herbal medicine. US: Dorling Kindersley; 2016.

12. Zupanets KO, Shebeko SK, Ratushna KL. Cumulative risks of excipients in paediatric phytomucolytic syrups: the implications for pharmacy practice. Sci Pharm. 2021;89(3): 32. Available from: https://doi.org/10.3390/ scipharm89030032.

temat. nomer «Pediatriia». 2019;4(51):23. Available from: http://www.health-ua.com . Ukrainian.

7. Kardosh P. [Phytotherapy in acute bronchitis: What evidence do we have?]. Zdorovia Ukrainy. 2019;18(463): 43-4. Available from: http://www.health-ua.com. Ukrainian.

8. Antimicrobial-resistant pathogens associated with healthcare-associated infections: summary of data reported to the National Healthcare Safety Network at the Centers for Disease Control and Prevention, 2009-2010. Infect Control Hosp Epidemiol. 2013;34(1): 1-14. Available fromL doi/org/10.1086/668770. Epub 2012 Nov 27

9. Kardos P. Phytotherapy in acute bronchitis: what is the evidence? Clinical Phytoscience. 2015;1: 2. DOI: 10.1186/s40816-015-0003-2.

10. Chernykh VP, Zupanets IA, Lischishina OM. Protocols of Pharmaceutist (Pharmacist) [Протоколи провізора (фрармацевта)]. Kharkiv: NUPh: Zoloti storinky. 2014. Ukrainian.

11. Chevallier A. Encyclopedia of herbal medicine. US: Dorling Kindersley; 2016.

12. Zupanets KO, Shebeko SK, Ratushna KL. Cumulative risks of excipients in paediatric phytomucolytic syrups: the implications for pharmacy practice. Sci Pharm. 2021;89(3): 32. Available from: https://doi.org/10.3390/ scipharm89030032.

\section{Відомості про авторів}

Зупанець К. О. - д. фармац. наук, професор, завідувач кафедри клінічної фрармакології та клінічної фрармації, Національний фрармацевтичний університет МОЗ України, Харків, Україна. E-mail: katyazupanets@gmail.com, ORCID ID 0000-0002-3458-4273

Сахарова Т. С. - д. фрармац. наук, професор кафредри клінічної фрармакології та клінічної фрармації, Національний фрармацевтичний університет МОЗ України, Харків, Україна. E-mail: ssts2012.2010@gmail.com, ORCID ID 0000-00026815-1695

Безугла Н. П. - канд. мед. наук, доцент кафедри клінічної фрармакології та клінічної фрармації, Національний фармацевтичний університет МО3 України, Харків, Україна. E-mail: npbezugla@gmail.com, ORCID ID 0000-0002$6420-2547$

ISSN 2312-0967. Pharmaceutical review. 2021. № 4 
Отрішко І. А. - канд. фрармац. наук, доцент кафедри клінічної фрармакології та клінічної фрармації, Національний фрармацевтичний університет МО3 України, Харків, Україна. E-mail: innaotrishko@gmail.com, ORCID ID 0000-00029089-8576

Шебеко С. К. - Д. фрармац. наук, професор кафедри клінічної фрармакології та клінічної фрармації, Національний фрармацевтичний університет МОЗ України, Харків, Україна. E-mail: shebeko.sk@gmail.com, ORCID ID 0000-00019350-7588

Ратушна К. Л. - канд. фрармац. наук, доцент кафедри клінічної фрармакології та клінічної фрармації, Національний срармацевтичний університет МО3 України, Харків, Україна. E-mail: pharmaxena@gmail.com, ORCID ID 0000-00022604-2829

\section{Information about the authors:}

Zupanets K. O. - DSc (Pharmacy), Professor, Head of the Department of Clinical Pharmacology and Clinical Pharmacy, National University of Pharmacy of the Ministry of Health of Ukraine, Kharkiv, Ukraine. E-mail: katyazupanets@gmail.com, ORCID ID 0000-0002-3458-4273

Sakharova T. S. - DSc (Pharmacy), Professor of the Clinical Pharmacology and Clinical Pharmacy Department, National University of Pharmacy of the Ministry of Health of Ukraine, Kharkiv, Ukraine. E-mail: ssts2012.2010@gmail.com, ORCID ID 0000-0002-6815-1695

Bezugla N. P. - PhD (Medicine), Associate Professor of the Department of Clinical Pharmacology and Clinical Pharmacy, National University of Pharmacy of the Ministry of Health of Ukraine, Kharkiv, Ukraine. E-mail: npbezugla@gmail.com, ORCID ID 0000-0002-6420-2547;

Otrishko I. A. - PhD (Pharmacy), Associate Professor of the Department of Clinical Pharmacology and Clinical Pharmacy, National University of Pharmacy of the Ministry of Health of Ukraine, Kharkiv, Ukraine. E-mail: innaotrishko@gmail.com, ORCID ID 0000-0002-9089-8576;

Shebeko S. K. - DSc (Pharmacy), Professor of the Department of Clinical Pharmacology and Clinical Pharmacy, National University of Pharmacy of the Ministry of Health of Ukraine, Kharkiv, Ukraine. E-mail: shebeko.sk@gmail.com, ORCID ID 0000-0001-9350-7588

Ratushna K. L. - PhD (Pharmacy), Associate Professor of the Department of Clinical Pharmacology and Clinical Pharmacy, National University of Pharmacy of the Ministry of Health of Ukraine, Kharkiv, Ukraine. E-mail: pharmaxena@gmail. com, ORCID ID 0000-0002-2604-2829 